\title{
Kliniske registre må utnyttes bedre
}

Som leder for forskerlinjen ved Det medisinske fakultet i Trondheim gleder jeg meg over kvaliteten og mangfoldet i studentenes prosjekter. Det gir håp for fremtiden. Eksempler på studentenes forskningsinnsats har flere ganger også blitt presentert i Tidsskriftet (1, 2). Men trass i mangfoldet, er det likevel ett stort medisinsk forskningsfelt som nærmest glimrer ved sitt fravær: den kliniske forskningen. Det ses tydelig når man går igjennom abstraktene til den årlige forskerlinjekonferansen, Frampeik (3). Det er kanskje ikke overraskende at studenter som velger oppgave tidlig i studiet, ikke forsker klinisk, men dette kan også speile et generelt problem. I invitasjonen til årets konferanse $\mathrm{i}$ april hevdet foreningen av nordiske universitetssykehus at den kliniske forskningen i regionen generelt sett er i tilbakegang og at halvparten av den industrisponsede kliniske forskningen har forsvunnet (4). Foreningens påstand om at klinisk forskning er på retur, kan trolig støttes av en opptelling jeg har gjort ved mitt eget fakultet: Sammenliknet med 2005 ble det avlagt dobbelt så mange doktorgrader i 2010, men andelen avhandlinger med en klar klinisk profil gikk samtidig ned.

Helseregistrene gir store muligheter for klinisk forskning. Sentrale landsdekkende helseregistre i Norge er kjent for sin høye kvalitet og har har vært brukt til å fremskaffe ny kunnskap av stor betydning for klinisk medisin og det offentlige helsevesen. Det er nok å nevne Kreftregisteret, Medisinsk fødselsregister og Meldingssystem for smittsomme sykdommer. Ved siden av dette, men ikke desto mindre viktig, ble det takket være engasjerte fagpersoner frem til midten av 1990-årene også opprettet et lite antall landsdekkende medisinske kvalitetsregistre. Et eksempel på verdien og betydningen av slike kliniske registre belyses i denne utgaven av Tidsskriftet (5). Med data fra det nasjonale leddproteseregisteret har Espehaug og medarbeidere ved Haukeland universitetssykehus vist at den aldersog kjønnsjusterte hyppigheten av primære hofteproteser økte med nær $30 \%$ i perioden 1989-2008. Den kraftigste økningen fant sted i siste del av 1990-årene. Selv om det ble påvist forskjeller mellom fylker og regioner, avtok de gradvis, med Helse Midt-Norge på topp og Helse Nord på bunn mot slutten av perioden.

En styrke ved tverrsnittsanalyser er at de kan benyttes til å anslå ressursbehov for gitte prosedyrer og tilbud av helsetjenester. Noe av det mest verdifulle med arbeidet til Espehaug og medarbeidere er at gjentatte tverrsnittsanalyser kan brukes til å vurdere ressursbehovet over tid (5). Slik studien er beskrevet, holder den høy kvalitet og det er ingen grunn til å trekke funnene i tvil. Men som $i$ alle gode studier resulterte undersøkelsen i at forfatterne selv stilte flere spennende spørsmål: Hva ligger bak de observerte forskjellene? Hva innebærer det at hyppigheten av primære hofteproteser er stabil over tid? Blir det operert for få hoftepasienter?

Registrene kan og bør også brukes til slike mer analytiske formål. Et eksempel på dette er hvordan norske og australske forskere organiserte data fra leddproteseregisteret i definerte pasientkohorter og gjennomførte prospektive analyser og predikerte effektene - både positive og negative - av primær hofte- og kneprotese (6). Dette avdekket klare forskjeller i utfallet mellom tidspunktet for operasjon og ulike protesetyper. Overlevelsesanalyser viste at $95 \%$ av protesene fungerte godt ti år etter inngrepet.

Spørsmålet er om det blir mer og bedre klinisk forskning med økt bruk av registerdata. Det forutsetter i så fall at man for det første klarer å utnytte registrenes potensial. Samtidig må det tas tilstrekkelig hensyn til at klinisk forskning innbefatter mye mer pasientrettet nærkontakt enn helseregisterforskning, selv om sistnevnte også er ment å brukes til å forbedre helsetjenesten både for pasientgrupper og enkeltpasienter. I kjølvannet av helseregisterloven (2001) og helseforetaksreformen (2002) er det etablert et omfattende tilfang av landsdekkende helseregistre og medisinske kvalitetsregistre (7). Selv om oppbyggingen av gode registre kan føre til at forventningene om bedre forskning og klinisk behandling etter hvert kan bli innfridd, står motforestillingene i kø. Blant annet ble hensynet til personvernet nylig drøftet på denne plass (7). En annen utfordring er at mange av registrene foreløpig bare har lokal eller regional forankring selv på viktige områder som hjertesykdommer og slag og at det vil kreve en omfattende innsats å få dem samkjørt på nasjonalt nivå. Det er nok heller ingen tilfeldighet at psykiatri, rus og geriatri henger etter i etableringen av nasjonale kvalitetsregistre. Problemene på disse feltene av sammensatte lidelser utgjør en stor utfordring både til valg av metode og gjennomføring av kliniske studier.

Det er også vanskelig å komme utenom at ytre rammevilkår kan ha negativ innvirkning på klinisk forskning (8). Noen eksempler er urealistiske reduksjoner i tjenesteplaner, brudd på arbeidstidsbestemmelser, utstrakt bruk av vikarer og bevisst bruk av lave stillingsandeler. Parolen er innlysende: Mer produksjon og mindre fordypning. Resultatet er like klart: Det blir mindre sammenhengende tid til egen forskning og veiledning av andre, for eksempel i form av fristende tilbud til fremtidige forskerlinjestudenter.

Adekvat fortolkning av kliniske data krever åpenbart klinisk innsikt og erfaring. Det innebærer en tydelig medvirkning fra klinikere som har generert dataene. Et samarbeid mellom kyndige klinikere og registerforskere er helt avgjørende for å oppnå best mulig utnyttelse av helseregistrene som grunnlag for bedre tilbud til pasientene. Håpet ligger, som nevnt, alltid i fremtiden. Derfor er det tross motforestillingene grunn til å vente at det omfattende engasjementet $i$ etableringen av dagens og fremtidige kvalitetsregistre vil bære frukter. Norske ortopeder har i så fall gått foran med et godt eksempel.

\section{Geir W. Jacobsen}

geir.jacobsen@ntnu.no

Geir Wenberg Jacobsen (f. 1945) er cand.med. og Dr.P.H., professor i samfunnsmedisin ved Norges teknisk-naturvitenskapelige universitet og medisinsk redaktør i Tidsskriftet.

Ingen oppgitte interessekonflikter.

\section{Litteratur}

1. Hem E. Kartlegging av hjernens navigasjonssystemer. Tidsskr Nor Legeforen 2011; 131: 654 .

2. Hem E. Neopterin predikerer hjertedød ved diabetes. Tidsskr Nor Legeforen $2011 ; 131: 655$

3. Frampeik. Legestudentenes forskningskonferanse 22.-24. oktober 2010. http://org.ntnu.no/frampeik2010/?q=symposier (19.5.2011).

4. Nordic University Hospital Research Conference 11.-13.4.2011. www.nrcnetwork.com/ (19.5.2011).

5. Espehaug B, Furnes O, Engesæter LB et al. Hofteproteser i Norge 1989-2008. Tidsskr Nor Legeforen 2011; 131: 1543-6.

6. Hem E. Gode leddproteser. Tidssskr Nor Legeforen 2010; 130: 913.

7. Haug C. Retten til seg selv. Tidsskr Nor Legeforen 2010; 130: 587

8. Jacobsen GW. Dains me' mæ? Adresseavisen 31.3.2011. www.adressa.no/meninger/article1612053.ece (19.5.2011). 